\title{
Feedback Loop: \\ Reflections from a Peer Review-Intensive Seminar
}

\author{
Colin M. Brown*
}

\section{APSA Teaching and Learning Conference, Albuquerque, New Mexico | February 7-9, 2020}

Given the imperative to publish, the currency of the profession for most faculty is the peer-reviewed article or book; publications that go through the rigorous process of being evaluated by others with expertise in the field are deemed to be more authoritative. They are often also much better written, as the presentation itself has been evaluated by members of the target audience. Feedback is presented to the author, and critiques are incorporated into the final product. Even before submitting to peer review, however, most academic authors seek intensive feedback on their work, as is apparent from a quick glance at the acknowledgements section of most articles or at the number of faculty writing groups facilitated by universities.

These benefits may make it worthwhile to offer students a similar opportunity, and to have them engage in peer-review processes to improve the quality of their writing and to force them to defend their ideas more rigorously, more clearly, and with better evidence. As project-based learning pedagogies increase in popularity outside the

\footnotetext{
*Assistant Teaching Professor, Northeastern University, colin.brown@northeastern.edu
} 
scientific and medical fields where they originated, student peer review in the classroom context offers a way to extend this approach to the writing process. Insofar as students are likely to work with colleagues on writing projects in their professional career, peer review may be a way to extend experiential learning to composition and writing. Whether

peer review at the undergraduate level is effective or not, however, largely remains to be seen, and within the larger field of peer assessment only a few peer-reviewed peer review writing studies have yet been generated in the higher education context.

This paper attempts to summarize the literature on student peer review of writing to show that we do have good theoretical reasons to expect peer review to be successful, but still lack robust studies to demonstrate the relationship. It then discusses a model course (currently being taught for the second time) where peer review is the core instructional method. Reflecting on the course, it is hard to draw initial conclusions, though the course was well-received by students and appeared to improve writing outcomes. Models are provided in the appendices for teachers who may wish to include more peer review in the undergraduate classroom, and all together it (hopefully) provides a guide to further and more rigorous explorations of peer review as a tool for teaching social science writing.

\section{Literature}

Peer review as a pedagogical tool resonates with several theoretical ideas of how students learn, and would appear to be a practical extension of these models. Boud and Molloy's work on a "sustainable assessment" model of feedback is commonly cited by in recent research. It argues for giving students more frequent feedback and helping them 
acquire more agency in seeking it. Researchers have also tied peer feedback models to ideas of authentic assessment and vicarious learning.

Boud and Molloy's idea of "sustainable assessment" sets up two contrasting approaches to providing student feedback. What they describe as an "engineering" model arose in the mid-20th century, and was modeled largely on industrial design. In this approach, teachers played the role of a the "control engineer" whose job was to observe outcomes and report them back into the system. If the system (i.e., the learner) adapted, this demonstrated learning (Wiener 1950). This model had important contrasts to early approaches to grading, which viewed grades purely as summative assessments. However, Boud and Molloy argue that as the engineering model of feedback was developed, the focus remained on the quality of the feedback given without any attention paid to whether the learners demonstrated any improvement, or indeed whether they internalize any of the feedback at all.

\footnotetext{
"Feedback became synonymous with 'telling,' that is the one-way transmission of information from teacher to students, as if students did not need to be involved and make their own judgements about what they should do. The assumption being that, if only students acted on what they were told, they could improve their performance." (701)
}

As they point out, this approach rests on a number of assumptions about how clear and unambiguous the feedback is, and whether students have the requisite skills to know how to put the feedback into practice. For highly specific skills where there is an opportunity for frequent exchange between the learner and instructor (in an apprenticeship, for example), there is evidence that the engineering model actually can work well. But in typical classroom settings, and with more open-ended skills like critical thinking or research design, the model appears to be impractical at best and possibly just ineffective (703). 
The alternative model that Boud and Molloy suggest has a number of features, but among the most critical are explicitly teaching students how to ask for help and ensuring that they have the tools to judge their own performance (706-7). In practical terms, they advocate for including feedback practice through low-stakes assessments early on before summative grading is done, and for providing students opportunities to assess their own work and, critically, to see how their own assessments differ from others, allowing them to "develop awareness of what they do and do not know or can and cannot do" (707).

One set of empirical findings may give some interesting context to Boud and Molloy's model. Insofar as students need to compare their own assessments to the assessments of others, getting both expert and peer assessments at the same time may not be necessary-and indeed may be harmful. Glaser (2014) argues that combining peer and instructor assessments might undermine students' trust in the results of the peer review process. If this happens, the additional feedback from students may not be seen as helpful; if it corresponds to the instructor's comments it may be seen as superfluous while if it contradicts it, it may be taken not as part of a range of possible reactions but as merely "incorrect." On the other hand, though, two studies have found that in some contexts the problem may present itself in exactly the opposite way. If students find their peers' language to be more accessible, they may act on the feedback they receive in this way and discount the comments of their instructors (Topping 1998; Nicol, Thomson \& Breslin 2014).

Peer review is also seen as a relatively authentic form of assessment that mirrors the kind of evaluation that students will likely receive in contexts beyond the classroom. In this way, student development of skills in giving and receiving feedback may well be developing "soft skills" of a kind often cited as in-demand and valuable in the 
contemporary labor market (Adachi, Tai \& Dawson 2018; Biswas \& Haufler 2018). One tension that Adachi, Tai \& Dawson point out is that peer assessment can focus either on providing summative or formative feedback. The literature on summative peer feedback has been developed more in the natural sciences, where it is seen as a way of reducing workload for faculty and for training students how to use assessment tools. ${ }^{2}$ In order for students to fairly evaluate others' work, however, it is crucial that they have a clear understanding of what the expectations and criteria for an assignment are. Modeling these through tools like rubrics can be done in a somewhat straightforward matter, and it is generally easier to measure how well students are applying the criteria and to calibrate this process itself in an iterative, engineering-feedback model (Adachi, Tai \& Dawson 2018). But if the goal is to encourage growth and not simply to assess, the evaluator needs to have some degree of empathy-and teaching empathy is as yet a much more vague process (Adachi, Tai \& Dawson 2018).

A related framework that suggests the value of peer review as an instructional tool is the idea of "vicarious learning," (Bandura 1969; Bandura 1982) which focuses on the idea of giving others feedback, watching them implement that feedback, and then applying the processes observed to one's own work either directly or through indirect means like reflective writing. This process is seen as giving students a chance to "learn how to learn" (Mayes et al 2002; Tai et al 2018). In this model, learners use their observations of how others process and adapt feedback to increase their own repertoire of tools and skills, in contexts relatively close to those in which they are expected to demonstrate knowledge. While this has been seen as a substitute for direct experiential

\footnotetext{
${ }^{2}$ See inter alia Van den Berg, Admiraal \& Pilot 2006; Sealey 2013; Li et al 2016; Demonacos, Ellis
} \& Barber 2019 
learning or direct feedback, there is some evidence from medical education that vicarious observation can, in many contexts, result in more successful learning than even direct participation (Stegmann et al. 2012; O'Regan et al 2018). Vicarious learning as a model does have some limitations in its adaptability to skills like writing, as it relies on students' ability to observe how feedback is utilized by others. While they can see the starting and ending products, they often cannot directly observe their peer's writing process. However, Nicol, Thomson and Breslin (2014) point out that students implicitly and internally make comparisons between their peers, and between their peers and themselves, throughout the peer assessment process. ${ }^{3}$ As such, as long as they have a chance to revise or reflect afterward, the feedback loop is completed and students can practice "learning how to learn."

These models sketch a vague picture of what might work, but suggest that a course allowing for more sustainable assessment, providing clear expectations, and allowing for students to observe others in the process of receiving and incorporating feedback could help create an environment for students to learn and internalize writing skills. It was with this in mind that the author developed a senior capstone course centered around the peer review process.

\section{Structure of the Course}

The initial goal of the course was to provide upper-level students who often had not had an opportunity for directed or independent study with the chance to examine their

\footnotetext{
${ }^{3}$ Tai et 2018 point out that the ability to make comparisons and evaluations is itself a skill which may be desirable to practice in the college classroom
} 
own topic, as well as to allow for "experiential learning" 4 in the writing process itself. The first iteration of the peer-review based capstone ran in the Spring of 2019, with 25 students (almost all in their final semester). All were political science majors, 12 of whom had an additional major. The course was one of three sections of the capstone offered to students that term, each centered on a different pedagogy (one of the other two was a traditional seminar; the other focused on a collaborative research project). Prior to course registration, students were given descriptions of the capstone options so that most students were able to choose the format that they preferred, with only a few exceptions due to course scheduling. This led to a somewhat self-selected group; students in this capstone section knew ahead of time that it was unusually writing-intensive but also that it offered more freedom in the choice of topic than the other seminars.

The course was structured almost entirely around its written assignments. Students were assigned six papers over the course of the semester, all on the same topic that they chose at the beginning (allowing for development or adjustment in the course of writing). Students first produced two book reviews; one for an academic journal and one for a more popular outlet such as the Boston Sunday Globe, the National Review, or the New York Review of Books. They then developed an op-ed where they were encouraged to make a clearer and more normative argument, before developing an academic literature review. Students were then given a choice of developing a TED-style talk or a guest lecture for an introductory politics course, and finally students produced a $\sim 15$ research paper on their topic. For each assignment, a rough draft and a final draft were submitted

\footnotetext{
${ }^{4}$ The university where the course has been offered has designated experiential learning as its signature pedagogical form.
} 
to their peers and to the instructor (for the literature review and research paper, students submitted an additional rough draft).

For each rough draft, a 100-minute class period was devoted to peer review. Students made physical or electronic copies available, and students read each other in class and then discussed their feedback as a group, working through each student's paper and feedback sequentially. The instructor provided a set list of questions that varied slightly for each assignment, to help suggest and model useful forms of feedback and to help keep peer review focused as students practiced it (See Appendix for examples) ${ }^{5}$. For the more academic writing styles, students were put into topical groups as closely as possible (education policy, security studies, etc.). For the popular writing styles, students were mixed so that they were working with peers who knew the field somewhat less well. The instructor joined a different group each session as a way of modeling feedback directly; early on in the semester the instructor submitted his own work for commentary to model receiving feedback and to encourage making oneself vulnerable to feedback (but did not do so later in the semester in order to give students more time for discussion).

Having to complete six papers and also get revisions on their work required almost constant deadlines, which both models many real-world work situations (requiring practice of time management) but also can add stress to already-busy students. To mitigate this, students were expressly reminded that first drafts did not need to be fully perfected, and a relatively lenient late policy was enacted on final drafts. However, students were required to have at least something to show and to workshop on peer review dates, so

\footnotetext{
${ }^{5}$ These questions were adapted for this course but drew inspiration from publicly available teaching materials from Abigail Fisher Williamson and Mirya Holman.
} 
rough drafts were required to be on time and students with illnesses/conflicts were required to seek out feedback from their peers as soon as feasible.

\section{Teaching Peer Review}

The class used a few different approaches to achieve one of its key goals: to go beyond teaching writing simply by having students do it repeatedly (cf. Boud and Molloy's engineering feedback model), and to offer models and guidance of what it actually means to give and receive good feedback on papers. The first approach was to use published works in the classrooms in what amounted to training or calibration sessions. Several published works were read for specific class sessions; for the popular book review, for example, students read a popular review of a political science book, a partisan political book, and a review of two related books at once. This provided models for their writing, but it also provided an opportunity to model giving feedback, and students practiced on each set of published examples by using the list of questions that they would use for each other's work in that particular genre. In the very first class session, the class used a technique called Generative Knowledge Interviewing that requires participants to hear how others process and summarize their own statements, engaging in a feedback process for both the interviewer and interviewee. By opening with this, the intent was to set expectations for structured exchange throughout the term. Lastly, as mentioned above, the instructor regularly joined in the process of giving feedback and at times subjected his own work to feedback as an imperfect model (including sharing the feedback from reviewers on the pieces they had critiqued). The instructor also provided comments on papers, but only after the final draft was submitted to allow students to complete a full 
cycle of the feedback process (or two) with their peer comments and to avoid the issues of competing authority of feedback mentioned above.

Students were assigned some additional reading to help in developing the project; Gerald Graff and Cathy Birkenstein's They Say, I Say served as a key text but students were also assigned guides for both the writing process and also for specific writing genres. A few other assigned short readings helped give students more clear explanations of the goals of academic writing, notably including posts from Raul Pacheco-Vega's blog.

Students were also given detailed grading rubrics against which their final drafts would be weighed, and were briefly instructed on how to use each in the interests of making clear expectations (See Appendix for examples).

\section{Reflections}

From a broad vantage point, the course appeared to have been successful, with students giving mostly positive reviews and the quality of writing noticeably improving for almost all students between early and later assignments.

The main source of positive comments given on student course evaluations did not focus directly on the peer review itself, although the few comments mentioning peer review were almost all positive. Students spoke positively about the ability to choose one's own assignment, and the cumulative nature of the writing assignments which allowed them to build on earlier skills (and on the work invested in earlier assignments as the semester progressed). Some students indicated that certain assignments seemed unnecessary, but there was no agreement on which assignments were seen as more or less useful, as some students indicated a desire to focus more on the kind of practical 
writing that they would do after graduation (such as the op-ed) while some wanted it to be a chance to demonstrate the ability to write a more advanced research paper-and one or two students specifically praised the wide variety of styles as a set.

Negative comments on evaluations tended to relate to the idea of a writing-focused course itself, and particularly on the fact that the course contained writing instruction qua writing instruction. A number of students felt that earlier courses had covered everything they needed to be taught about writing, and the texts were seen as merely occasionally helpful references at best and (especially with the writing manuals) unnecessary at worst. ${ }^{6}$ In the second iteration of the course, the amount of reading has been cut down, assigned in larger batches less frequently, and class sessions have been built more completely around the assigned readings, including practice exercises so that students feel comfortable using the templates from the Graff and Birkenstein text book. (See Appendix for the two syllabi for comparison). A few students mentioned that the accountability to the instructor for the draft deadlines added stress, and so building accountability to each other as much as or more than to the instructor may be worth further emphasizing and may not have been fully realized in the first version of the class.

Building in work sessions, where the class operated like a study hall (or many faculty writing groups), was popular and students requested even more of this in class evaluations. However, there may be a need to enforce attendance or to limit the amount of such time due to departmental climate, accreditation requirements, and university policies. The instructor's presence at these sessions to offer informal one-on-one advice

\footnotetext{
${ }^{6}$ As one student wrote, "Please stop making students spend money on textbooks about writing."
} 
and to take part in the writing sessions also allows for more individual connections and feedback, as well as a chance to model writing habits. ${ }^{7}$

At least three students indicated to the instructor that they had used writing samples from the class in applications for full-time employment after graduation before the term even ended. For this reason, it may be helpful to emphasize future sections the class specifically as a chance to build a writing portfolio. There are likely returns to careful and deliberate use of technology (like digital portfolios) to allow students to more easily showcase their work beyond graduation. Students were also encouraged to think about revisiting their book reviews and op-eds for publication, and at least one student op-ed from the class was published in a regional newspaper before the end of the semester.

This amount of writing submitted presents a considerable grading challenge for the instructor, and this proved to be a problem from the beginning. The instructor had originally planned to only offer detailed feedback on a select number of papers. However, the instructor did not hold himself to that standard and eventually needed to give extensive feedback on all papers, for all students, to maintain equity-something that took much more time than anticipated since the course was meant to emphasize the feedback from peers. In the second iteration of the course, the instructor set up additional mechanisms to clarify expectations with regard to instructor comments and to commit students to receiving detailed instructor feedback only on specific graded assignments.

So, despite the fact that peer review was critical to the design of the course, it is unfortunately hard to draw firm conclusions about the specific effectiveness of this

\footnotetext{
${ }^{7}$ And, in purely self-interested terms, up to a few extra hours for the instructor to write during the semester.
} 
element of the course design from the first iteration of this course. Students seemed to enjoy it and benefit from it during class sessions, but rarely mentioned the peer review process in their own comments. From the instructor's viewpoint, there was considerable improvement in writing skills over the course of the semester, but the sheer amount of writing assigned and the amount of instructor feedback given could potentially also account for these changes. This experience worked well as a "proof of concept" that a peer-review focused course could be successfully carried out, but further work remains to establish whether peer assessment is the key mechanism in this kind of course or whether simply making students do more writing-following Boud and Molloy's engineering model instead of thinking about their recommended form of "sustainable assessment"-might work after all.

\section{References}

Adachi, Chie, Joanna Hong-Meng Tai, and Phillip Dawson. "Academics' perceptions of the benefits and challenges of self and peer assessment in higher education." Assessment \& Evaluation in Higher Education 43.2 (2018): 294-306.

Bandura, Albert. Principles of Behavior Modification. New York: Holt, Rinehart and Winston, 1969.

Bandura Albert. Social Foundations of Thought and Action: A Social Cognitive Theory. Englewood Cliffs, NJ: Prentice Hall 1986.

Biswas, Bidisha, and Virginia Haufler. "What Can I Do with This Class? Building Employment-Related Skills in International Relations Courses." Journal of Political Science Education (2018): 1-12.

Boud, David, and Elizabeth Molloy. "Rethinking models of feedback for learning: the challenge of design." Assessment \& Evaluation in higher education 38.6 (2013): 698-712.

Demonacos, Constantinos, Steven Ellis, and Jill Barber. "Student Peer Assessment Using Adaptive Comparative Judgment: Grading Accuracy versus Quality of Feedback." Practitioner Research in Higher Education 12.1 (2019): 50-59. 
Glaser, Rainer E. "Design and Assessment of an Assignment-Based Curriculum to Teach Scientific Writing and Scientific Peer Review." Journal of Learning Design 7.2 (2014): 85-104.

Graff, Gerald and Cathy Birkenstein. They Say/I Say: The Moves that Matter in Academic Writing. $4^{\text {th }}$ ed. New York: W.W. Norton, 2014.

$\mathrm{Li}$, Hongli, et al. "Peer assessment in the digital age: a meta-analysis comparing peer and teacher ratings." Assessment \& Evaluation in Higher Education 41.2 (2016): 245-264.

Mayes, Terry, et al. "Learning from watching others learn." In Christine Steeples and Chris Jones, ed., Networked learning: perspectives and issues, Springer: London, 2002. 213-227.

Nicol, David, Avril Thomson, and Caroline Breslin. "Rethinking feedback practices in higher education: a peer review perspective." Assessment \& Evaluation in Higher Education 39.1 (2014): 102-122.

O'Regan, Stephanie, et al. "Observer roles that optimise learning in healthcare simulation education: a systematic review." Advances in Simulation 1.1 (2016): 4.

Sealey, Rebecca Maree. "Peer assessing in Higher Education: perspectives of students and staff." Education Research and Perspectives 40 (2013): 276-298.

Stegmann, Karsten, et al. "Vicarious learning during simulations: is it more effective than hands-on training?." Medical education 46.10 (2012): 1001-1008.

Tai, Joanna, et al. "Developing evaluative judgement: Enabling students to make decisions about the quality of work." Higher Education 76.3 (2018): 467-481.

Topping, Keith. "Peer assessment between students in colleges and universities." Review of educational Research 68.3 (1998): 249-276.

van den Berg, Ineke, Wilfried Admiraal, and Albert Pilot. "Design principles and outcomes of peer assessment in higher education." Studies in Higher education 31.03 (2006): 341-356.

Wiener, Norbert. The Human Use of Human Beings: Cybernetics and Society. Boston: Houghton Mifflin, 1950. 


\section{Peer Review Coversheet - POLS 4701 - Popular Book Review}

In general, what is working well in the draft?

Does the draft provide sufficient orientation to convince the reader why s/he should read the book? To convince the reader why s/he should read this review?

Does the draft include sufficient background information to allow the reader to follow the argument? If not, how could the author improve?

Were the paragraphs ordered in a way that was clear and supported both the book author's and the review writer's arguments? Was it clear whether each point came from the book author or the review writer? 
Does each paragraph contain a single idea, or a single theme? Does each clearly relate to the larger argument?

Are there any places where the language is unclear or imprecise? Where a meaning "sounds funny"?

Is there any place where the review writer expresses a concept in more words than necessary? Is there anywhere that the book could be more succinctly paraphrased and keep the meaning?

What is the biggest flaw you see in their writing? Is it a matter of the interpretation, or is it purely a matter of the writing style/tone/quality? 


\section{Peer Review Coversheet - POLS 4701 - Op-Ed}

In general, what is working well in the draft?

Is the author's opinion clearly stated? Is it clear whether their goal is to educate or to spur action?

Does the draft include sufficient background information to allow the reader to follow the argument? If not, how could the author improve?

Were the paragraphs ordered in a way that was clear and supported the author's main point? Does each paragraph contain a single idea, or a single theme? Does each clearly relate to the larger argument? 
Are there any places where the language is unclear or imprecise? Where a meaning "sounds funny"?

Is there any place where the writer uses language that is too direct? That is too indirect?

Are there places where the rhetoric is especially effective? Alternatively, are there places where the rhetoric comes across as confusing or overwrought?

What is the biggest flaw you see in their writing? Is it a matter of the interpretation, or is it purely a matter of the writing style/tone/quality? 


\section{More Important}

The review:

- Clearly states the book's

Does the review clearly express the points made in the book?

- Restates the author's points

- Simplifies or draws

The review:

Does the review make it clear whether/why

the book should be read?

Does the paper The review:

engage with $\bullet$ acknowledges disagreements authors' arguments, identifying areas of agreement and disagreement, concluding with an arguable viewpoint? primary arguments in a way that makes it accessible to those who have not read the book correctly and fairly connections between points made in the book, perhaps more succinctly than the author book's worth and role, with sufficient examples or evidence

- Places the book's merit in context of the broader academic conversation
- Clearly states most or all of the book's primary arguments in a way that makes it accessible to those who have not read the book

- Restates the author's points correctly and fairly

- Clearly states some or most of the book's primary arguments in a way that makes it accessible to those who have not read the book to the author are interpreted

- Gives a clear opinion of the book's worth and role, with some examples or evidence

- Places the book's merit in context of the broader academic conversation

- Gives a mostly clear opinion of the book's worth and role fully backed up

- Opinion may be
- Gives a clear opinion of the somewhat implicit

- Makes some mention of book's contribution to broader academic conversation

- Acknowledges obvious
disagreements with the book's author(s)

- is charitable to the evidence provided by the book

- provides evidence to support its own countervailing claims.

- is charitable to the evidence

- Acknowledges some disagreements with the book's author(s), some obvious disagreements not called out

Does not always provide sufficient provided by the book

- provides limited evidence to support its own countervailing claims. correct and fairly

- Opinions may not be

- Makes the books arguments or points unclear

OR

Inaccurately or unfairly portrays the authors' arguments

- Implicit or absent opinions

- No evidence given for opinions

- No connection to OR broader conversation

There is no clear introduction credence to author(s)' evidence

- provides limited evidence to support its own countervailing claims.
- Does not acknowledge disagreements

- provides no evidence to support its own countervailing claims. 
Excellent (A)

This review:

- Has a clear statement of the book's arguments

- Has clear takeaways for an academic audience, whether from the book's author(s) or its own observations

Is the overall organization coherent and does it fit the structure of a book review?

- Fits roughly within publication limits (800-1200 words)
Good (A-)

- Has a clear statement of the book's arguments

- Has takeaways for an academic audience, whether from the book's author(s) or its own observations, which are mostly clear on first reading

- Fits roughly within publication limits (800-1200 words)
Adequate ( $\mathrm{B}$ to $\mathrm{B}+$ )

- Contains the book's main arguments in an unexpected or difficultto-interpret structure

- May not clearly state takeaways for an academic audience

- Is long or short enough that a journal editor would request a rewrite $<600$ words or $>1400$ words

\section{Less Important}

\begin{tabular}{|l|l|l}
\hline Does the & The evidence is: & c cited properly, with 1-2
\end{tabular}

author

succinctly

summarize or paraphrase

and

meaningfully, but sparingly, quote properly cited evidence?

Grammar, spelling, and sentence structure:

- meets conventional

Does the paper demonstrate evidence of proofreading and correct grammar and spelling?

- cited properly

- quoted when exact phrasing is - presented in a variety of crucial to making the author's formats (quoting, point

- otherwise succinctly paraphrased or summarized paraphrasing, and summarizing)

- may be occasionally quoted when exact phrasing from the original author is not necessary academic writing standards

- Generally, meets conventional academic writing, though the writing may occasionally be too informal or minimally interfere with clarity errors, but they do not interfere with the clarity of the paper
There may be a few $(3+)$ errors that catch the reader's attention, but do not significantly interfere with clarity only adequately cited, with several instances of unattributed works

- excessively quoted OR inaccurately paraphrased or summarized grammar/sentence structure may from the clarity of the paper significantly distract
Poor (B- or lower)

- Does not clearly signal the book's primary argument

- Does not have an obvious takeaway

- Does not observe word limits not cited, even where clearly necessary

- excessive use of direct quotes as "filler" grammar/sentence structure significantly distracts from the clarity of the paper

- reflects carelessness and lack of attention to detail 


\begin{tabular}{|c|c|c|c|c|}
\hline \multicolumn{5}{|c|}{ TED Talk or Guest Lecture } \\
\hline $\begin{array}{l}\text { Does the talk } \\
\text { have a clear } \\
\text { purpose or } \\
\text { takeaway? }\end{array}$ & 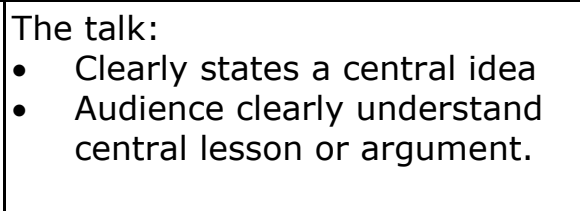 & 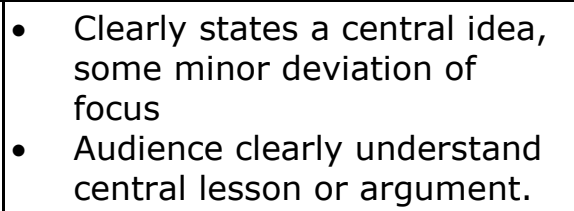 & $\begin{array}{l}\text { - } \quad \text { Central idea visible, but implicit } \\
\text { - } \\
\text { not fully see or agree on central } \\
\text { lesson or argument }\end{array}$ & $\begin{array}{ll}\text { - } & \text { No central idea } \\
\text { OR } & \\
\text { - } & \text { Audience cannot } \\
& \text { determine central } \\
\text { idea }\end{array}$ \\
\hline $\begin{array}{l}\text { Does the talk } \\
\text { address its } \\
\text { target } \\
\text { audience? }\end{array}$ & $\begin{array}{l}\text { The talk: } \\
\text { - Uses language easily } \\
\text { understood by target } \\
\text { audience } \\
\text { Does not assume too } \\
\text { much/too little background } \\
\text { knowledge } \\
\text { Is forthright about its own } \\
\text { assumptions or biases, if any } \\
\text { Explains the topic and } \\
\text { takeaway clearly for non- } \\
\text { experts }\end{array}$ & 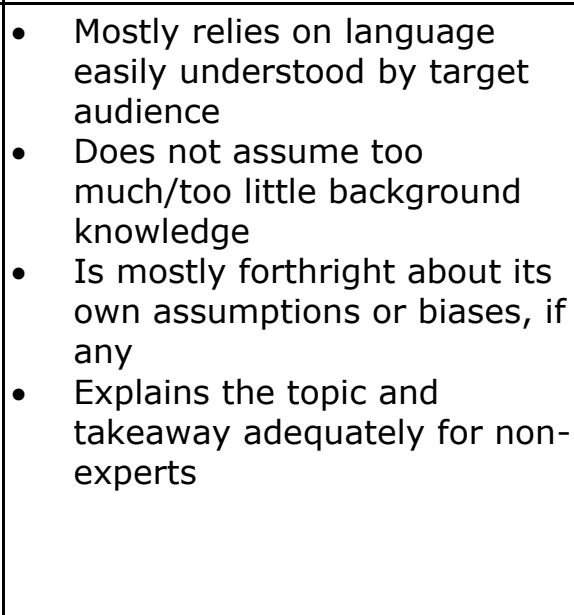 & $\begin{array}{l}\text { - Some excessive jargon or unclear } \\
\text { language that obscures particular } \\
\text { points, but main point is clear } \\
\text { Mostly does not assume too } \\
\text { much/too little background } \\
\text { knowledge } \\
\text { Is mostly forthright about its own } \\
\text { assumptions or biases, if any } \\
\text { Explains the topic and takeaway } \\
\text { adequately such that non-experts } \\
\text { would understand most but not all } \\
\text { of the presentation }\end{array}$ & 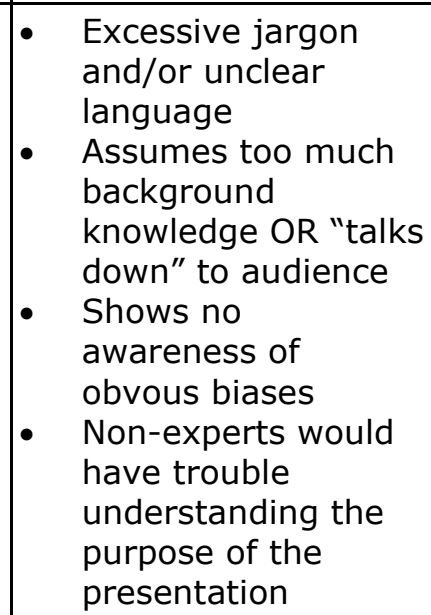 \\
\hline $\begin{array}{l}\text { Does the talk } \\
\text { provide an } \\
\text { appropriate } \\
\text { amount of } \\
\text { evidence? }\end{array}$ & $\begin{array}{l}\text { The talk: } \\
\text { - } \quad \text { Provides evidence for any } \\
\text { contentious claim or claim } \\
\text { that is not self-evident } \\
\text { - } \quad \text { ites sources where } \\
\text { appropriate (in manner } \\
\text { appropriate to spoken } \\
\text { communication) }\end{array}$ & $\begin{array}{l}\text { Provides evidence for most } \\
\text { contentious claims or claims } \\
\text { that are not self-evident } \\
\text { Cites sources where } \\
\text { appropriate (in manner } \\
\text { appropriate to spoken } \\
\text { communication) }\end{array}$ & $\begin{array}{l}\text { Provides evidence for most but } \\
\text { noticeably not all contentious } \\
\text { claims } \\
\text { One or two major points or ideas } \\
\text { from others remain unattributed }\end{array}$ & $\begin{array}{l}\text { Few claims are } \\
\text { backed up by } \\
\text { evidence } \\
\text { Does not attribute } \\
\text { points obviously } \\
\text { drawn from others }\end{array}$ \\
\hline $\begin{array}{l}\text { Is the talk } \\
\text { organized } \\
\text { effectively? }\end{array}$ & $\begin{array}{l}\text { The talk: } \\
\text { - Is organized around a central } \\
\text { idea in a way that } \\
\text { emphasizes the talk's primary } \\
\text { point } \\
\text { - Evidence and narratives are } \\
\text { introduced in an appropriate } \\
\text { context } \\
\text { Does not contain tangents or } \\
\text { extraneous details which do } \\
\text { not come back to central } \\
\text { point }\end{array}$ & $\begin{array}{l}\text { - Is organized around a central } \\
\text { idea in a way that } \\
\text { emphasizes the talk's primary } \\
\text { point } \\
\text { Evidence and narratives are } \\
\text { mostly introduced in an } \\
\text { appropriate context } \\
\text { May contain a few extraneous } \\
\text { details, but they remain on } \\
\text { topic and do not distract from } \\
\text { central point }\end{array}$ & $\begin{array}{l}\text { - Is organized a central idea in a way } \\
\text { that mostly emphasizes the talk's } \\
\text { primary point } \\
\text { Evidence and narratives may } \\
\text { occasionally be introduced before } \\
\text { audience has enough context or } \\
\text { else as "afterthoughts" } \\
\text { May contain a few extraneous } \\
\text { details, but they remain on topic } \\
\text { and do not distract from central } \\
\text { point }\end{array}$ & \begin{tabular}{|l|} 
- Central idea unclear \\
and organization \\
does not provide \\
cues \\
Evidence and \\
narratives are on \\
topic but seem \\
randomly introduces \\
Many extraneous \\
details
\end{tabular} \\
\hline
\end{tabular}




\begin{tabular}{|c|c|c|c|c|}
\hline \multicolumn{5}{|c|}{ TED Talk } \\
\hline $\begin{array}{l}\text { Is the talk } \\
\text { presented in } \\
\text { a compelling } \\
\text { way? }\end{array}$ & $\begin{array}{l}\text { The talk: } \\
\text { Balances logical, emotional } \\
\text { and ethical appeals in a } \\
\text { compelling way likely to } \\
\text { change minds } \\
\text { Uses rhetorical devices in a } \\
\text { way that enhance the clarity } \\
\text { and/or effectiveness of the } \\
\text { argument }\end{array}$ & $\begin{array}{l}\text { Balances logical, emotional } \\
\text { and ethical appeals in a } \\
\text { compelling way likely to } \\
\text { change minds } \\
\text { Uses rhetorical devices in a } \\
\text { way that enhance the clarity } \\
\text { and/or effectiveness of the } \\
\text { argument }\end{array}$ & $\begin{array}{l}\text { Relies more on logic, emotion and } \\
\text { or ethics than appropriate to } \\
\text { central opinion or topic } \\
\text { Rhetorical devices may sometimes } \\
\text { obscure instead of clarify }\end{array}$ & $\begin{array}{l}\text { Does not balance } \\
\text { different kinds of } \\
\text { appeals } \\
\text { Rhetorical devices } \\
\text { obscure or "show } \\
\text { off" more than } \\
\text { clarify }\end{array}$ \\
\hline $\begin{array}{l}\text { Is the } \\
\text { audience's } \\
\text { mind } \\
\text { changed? }\end{array}$ & $\begin{array}{l}\text { The audience } \\
\text { - Is likely to have begun the } \\
\text { talk with one understanding } \\
\text { or idea, and is likely to have } \\
\text { updated their understanding } \\
\text { or changed their idea }\end{array}$ & $\begin{array}{l}\text { Is likely to have begun the } \\
\text { talk with one understanding, } \\
\text { and is likely to acknowledge } \\
\text { the evidence or arguments } \\
\text { for a different idea }\end{array}$ & $\begin{array}{l}\text { Is likely to have understood your } \\
\text { central argument but been } \\
\text { unmoved or unconvinced }\end{array}$ & - Is unimpressed \\
\hline \multicolumn{5}{|c|}{ Guest Lecture } \\
\hline $\begin{array}{l}\text { Is the talk } \\
\text { presented in } \\
\text { a compelling } \\
\text { way? }\end{array}$ & $\begin{array}{l}\text { The talk: } \\
\text { - Balances logical, emotional } \\
\text { and ethical appeals in a way } \\
\text { that is likely to aid } \\
\text { understanding and retention } \\
\text { - Uses rhetorical devices in a } \\
\text { way that enhance the clarity } \\
\text { and/or effectiveness of the } \\
\text { argument }\end{array}$ & $\begin{array}{l}\text { Balances logical, emotional } \\
\text { and ethical appeals in a way } \\
\text { that is likely to aid } \\
\text { understanding and retention } \\
\text { Uses rhetorical devices in a } \\
\text { way that enhance the clarity } \\
\text { and/or effectiveness of the } \\
\text { argument }\end{array}$ & $\begin{array}{l}\text { Relies more on logic, emotion and } \\
\text { or ethics than appropriate to } \\
\text { learning a new topic } \\
\text { Rhetorical devices may sometimes } \\
\text { obscure instead of clarify }\end{array}$ & $\begin{array}{l}\text { Does not balance } \\
\text { different kinds of } \\
\text { appeals } \\
\text { Rhetorical devices } \\
\text { obscure or "show } \\
\text { off" more than } \\
\text { clarify }\end{array}$ \\
\hline $\begin{array}{l}\text { Did the } \\
\text { audience } \\
\text { learn } \\
\text { something? }\end{array}$ & $\begin{array}{l}\text { The audience } \\
\text { Is likely to leave with a new } \\
\text { framework of understanding } \\
\text { that allows them to retain } \\
\text { new knowledge and explain } \\
\text { the topic in detail }\end{array}$ & $\begin{array}{l}\text { Is likely to leave with a } \\
\text { memory of the broad } \\
\text { contours of the topic and } \\
\text { many details } \\
\text { May only somewhat be able } \\
\text { to connect to other } \\
\text { topics/previous knowledge }\end{array}$ & $\begin{array}{l}\text { Is likely to leave with a memory of } \\
\text { some details but unable to describe } \\
\text { the topic in any depth } \\
\text { May only somewhat be able to } \\
\text { connect to other topics/previous } \\
\text { knowledge }\end{array}$ & $\begin{array}{l}\text { Understands your } \\
\text { explanation as you } \\
\text { give it but does not } \\
\text { retain any } \\
\text { knowledge } \\
\text { Cannot connect to } \\
\text { their previous } \\
\text { knowledge }\end{array}$ \\
\hline
\end{tabular}




\section{POLS 4701 - Senior Capstone \\ Spring 2019}

Mon/Weds 2:50pm - 4:30pm, Hastings 104

Instructor: Colin M. Brown

Phone: (617) 373-8192

E-mail: colin.brown@,northeastern.edu

Office: Renaissance Park 905

Office Hours: Appointments: Thursday 10-12am, RP 905 (sign up online), or by individual arrangement Walk-In: Friday 10-11:30am, Starbucks Coffee (273 Huntington Avenue)

\section{Overview}

Students graduating with a degree in political science will be expected to take an active role in the lives of their communities and in the intellectual conversation around politics and government. Much of this will involve communicating and writing their ideas for the consumption of others. While most coursework has focused on the substance of politics and political science, this course will emphasize how to convey ideas, theories, opinions and data to a variety of audiences through extensive writing practice. The course will also teach students how to offer constructive feedback, and provide a wide variety of chances to give and receive criticism.

In addition to the assignments and course readings, students will base all of their writing assignments on a single topic of interest. This can be anything in political science, but it must be consistent throughout the semester. In this way, students will be able to practice talking about the same topic in a variety of ways, and practice incorporating new material into existing ideas. Students should plan on completing a considerable amount of reading on their own and/or bringing in material from other courses, with the instructor available for advice and guidance.

\section{Course Learning Outcomes}

Students will be able to:

- Plan and write texts in a variety of styles appropriate to politics and to academic political science, including book reviews, literature reviews, editorial essays, public speeches, and research papers.

- Make revisions to their own writing based on peer review

- Critique others' writing on political and academic topics in a way that improves their writing and shows interpersonal respect

- Assimilate new data and theories into existing arguments, and adapt existing arguments to new evidence. 


\section{Assignments}

- Participation - 20\%: Students are expected to attend all class sessions, and be heavily involved in the peer review process. You will also be expected to take part in discussions of the reading material for weeks where there are assigned readings and in-class discussions.

- Writing Assignments - $\mathbf{8 0} \%$ Total: You will have a number of writing assignments due throughout the semester, and this will constitute the majority of your grade. The literature review and the research paper will be weighted at $16 \%$ of your total grade, and the other assignments will each be worth $12 \%$ of your total grade. Each assignment's grade will be determined on the following factors:

- $20 \%$ Timeliness

- $60 \%$ Satisfies the Goal of each Writing Style

○ $20 \%$ Quality of Writing (applies only to revised drafts.)

Final course grades will be calculated from total percentages, without rounding - A: $94 \%$ or above $\%$, A-: $90 \%$ to $93.99 \%$, B+: $87 \%$ to $89.99 \%$, B: $83 \%$ to $86.99 \%$, B-: $80 \%$ to $82.99 \%$, C+: $77 \%$ to $79.99 \%$, C: $73 \%$ to $76.99 \%$, C-: $70 \%$ to $72.99 \%$, D+: $67 \%$ to $69.99 \%$, F: $66.99 \%$ or below.

\section{Assignment Calendar (Is something due today?)}

For every day that a $1^{\text {st }}$ or $2^{\text {nd }}$ Draft is assigned, we will do peer review that day in class; plan to bring hard copies with you. Revised Drafts will be submitted via Blackboard. All assignments are due by the start of class that day $(2: 50 \mathrm{pm})$ with the exception of the Research Paper, as noted below.

- January 23: Academic Book Review 1 ${ }^{\text {st }}$ Draft

- January 30: Academic Book Review Revised

- February 6: Popular Book Review $1^{\text {st }}$ Draft

- February 13: Op-Ed 1st Draft

- February 20: Op-Ed Revised \& Popular Book Review Revised

- March 13: Literature Review $1^{\text {st }}$ Draft

- March 18: Literature Review 2 $2^{\text {nd }}$ Draft

- March 27: Guest Lecture or TED Talk $1^{\text {st }}$ Draft of Speech/Talking Points

- April 1 or April 3: Give Lecture or TED Talk (in class or recorded)

- April 8, 11:59pm: Research Paper 1 ${ }^{\text {st }}$ Draft

- April 15, 11:59pm: Research Paper 2nd Draft

- April 24, 11:59pm (during exams): Research Paper Final Draft

Due to the volume of writing and the size of the class, the instructor will be unable to provide detailed feedback on every piece of writing. The instructor will, however a) join in in-class peer review, b) offer detailed feedback on the revised literature review, and c) offer detailed feedback on one other assignment of each student's choice (students will sign up for these early in the semester).

You will also have the opportunity to build on your own work from one assignment to the next. The style and intended audience will change for each piece so you cannot simply copy and paste entire paragraphs, but you can (and should) use prior work to scaffold and improve your later work, and as such you may use some ideas and/or writing fragments more than once. 


\section{Reading Schedule}

This course is a chance for you to explore any topic that you have found interesting in your time as a political science student, and that you wish to examine in greater depth. You and your fellow students will be studying a wide range of themes and you may not overlap with what anyone else is doing---and that's fine! Your topic can evolve a bit as you read and discover things, but by January 16 $6^{\text {th }}$, you should have worked with the instructor (via office hours or e-mail) to determine a general topic that you will focus on for the semester.

Because of this opportunity to follow your own intellectual curiosity, the majority of reading you will do for this class will be on your own---you will be finding the materials you will draw on to write your literature review, book reviews, and research papers, and/or you will draw on things you have read before this class. While the assigned readings are relatively short, you should plan for considerable self-directed reading of books, academic articles, and reports. The instructor is always available to help you in your search, but this class is intended as an opportunity for intensive practice of the research skills you have acquired as an undergraduate.

\section{$\underline{\text { Required Texts: }}$}

- (P \& C) John Peck and Martin Coyle, Write it Right: The Secrets of Effective Writing, Palgrave Macmillan 2012 (2nd ed).

- (G \& B) Gerald Graff and Cathy Birkenstein, They Say, I Say: The Moves That Matter in Academic Writing, W.W. Norton 2018 (4th edition, but $3^{\text {rd }}$ edition is also fine---and likely cheaper)

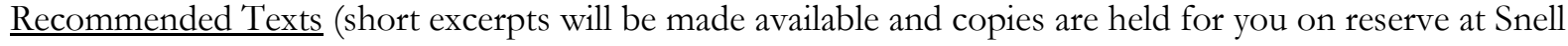
Library, but many of you will find it worthwhile to purchase the full book so that you can read further and refer back to these)

- (SP) Steven Pinker, The Sense of Style: The Thinking Person's Guide to Writing in the $21^{\text {st }}$ Century, Penguin 2014

- (LB) Lisa Baglione, Writing a Research Paper in Political Science: A Practical Guide to Inquiry, Structure, and Methods, CQ Press 2015

\section{Calendar}

$\circ$ January 7: G \& B, Introduction

○ January 9: P \& C, Chapters 1 \& 3

- January 14: G \& B, Chapters 1 \& 2 | Academic Book Review Examples (TBD)

- January 16: No readings

○ January 23: Harvard Bureau of Study Counsel, “A Procrastinator's Guide to Writing” | G \& B, Chapters 4 \& 5

○ January 28: Raul Pacheco-Vega's Blog: "How to Undertake a Literature Review," | Jeffery Knopf, "Doing a Literature Review," PS: Political Science and Politics 39(1) 2006: 127-132 | G \& B Chapters 3, 6 \& 7

- January 30: SP Chapter 3: "The Curse of Knowledge" | Popular Book Review Examples (TBD)

- February 4: G \& B, Chapters 8, 9, \& 10 | Elaine Campbell: "How I use Excel to Manage My Literature Review” | Raul Pacheco-Vega's Blog: “The Conceptual Synthesis Excel Dump (CSED) Technique" | Op-Ed Examples (TBD)

- February 6: No readings

- February 11: G \& B Chapters 12, 14, \& 17 | Laura Brown, How to Write Anything pp. 183-189, "Editorial" \& "Letter to the Editor" | More Op-Ed Examples (TBD)

- February 13: No readings 


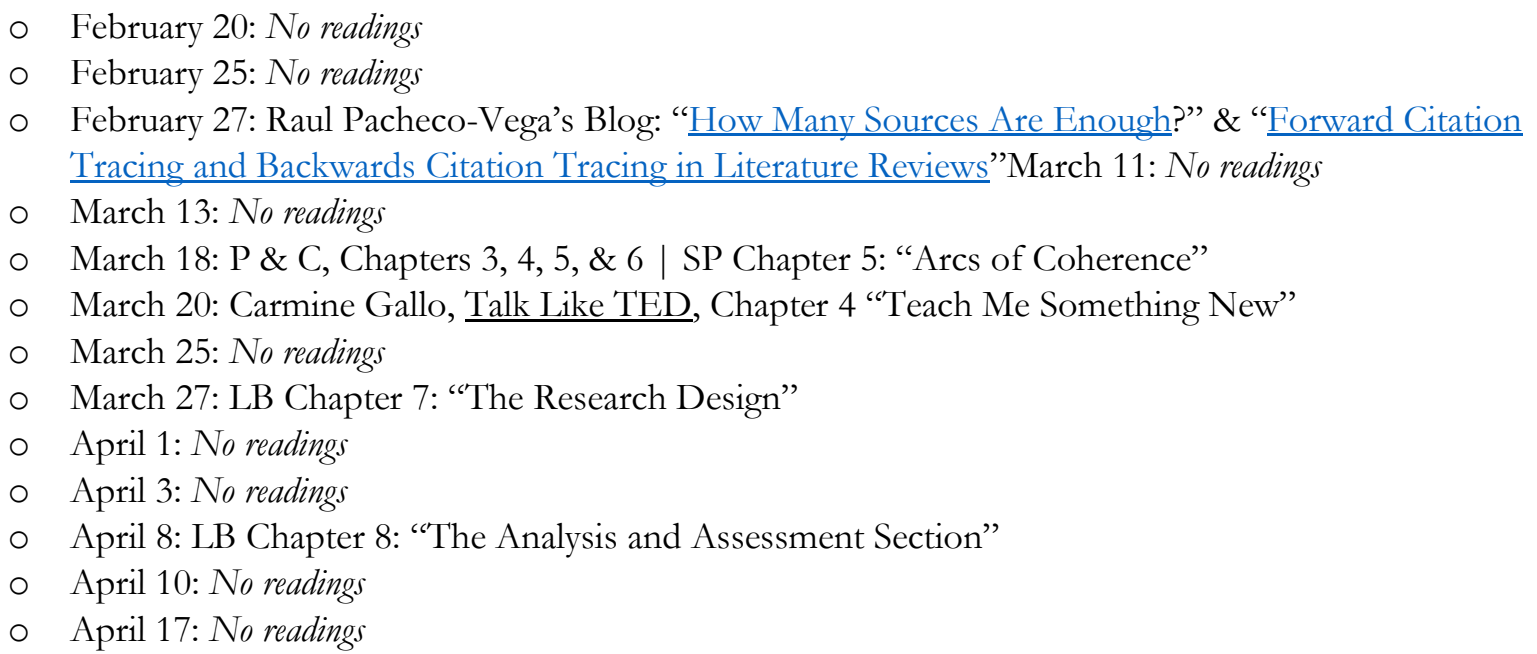

\section{Policies}

\section{Late Assignment Policy}

It is understood that students have a high workload and many different priorities during the semester. Therefore, any one revised version may be turned in up to one week late, without prior approval, but with a penalty equal to one letter grade. If you need to take this extension, simply e-mail the instructor before the due date indicating that your paper will be late. Because of the importance of peer review, drafts cannot be turned in late barring sickness or emergencies, and you should communicate these to the instructor as soon as possible.

\section{Academic Integrity}

The Department of Political Science takes very seriously the issue of academic honesty, and as set forth in Northeastern University's principles on Academic Honesty and Integrity Policy (the complete text can be found at Northeastern University's Office of Student Conduct and Conflict Resolution). Any student who appears to violate these principles will fail the course and will be put on academic probation. Individual faculty, with the support of the Department, can impose harsher penalties and as they deem necessary. Cheating is one example of academic dishonesty, and which is defined as using or attempting to use unauthorized materials, information, or study aids in any academic exercise. When completing any academic assignment, a student shall rely on his or her own mastery of the subject. Cheating includes plagiarism, which is defined as using as one's own the words, ideas, data, code, or other original academic material of another without providing proper citation or attribution. Plagiarism can apply to any assignment, either final or drafted copies, and it can occur either accidentally or deliberately. Claiming that one has "forgotten" to document ideas or material taken from another source does not exempt one from plagiarizing. Your instructor will clarify specific guidelines on fair use of material for this class.

Correct citation practices and academic honesty are an expectation of this course, but are also a skill students need to learn (and often need guidance on). If you are uncertain what to do in a situation, do not hesitate to ask the instructor beforehand to avoid creating a larger issue later.

\section{Resources}

\section{Campus Resources \& Services}


Students may face many barriers to learning in the course of their education, such as anxiety, depression, substance abuse, strained familial or romantic relationships, and others. Northeastern University provides you with a number of resources that may help you in whatever challenges you face, and help you find the space to succeed in your studies. University Health and Counseling Services (617-373-2772) has a wide variety of resources open to you, as do the centers and offices below:

- Center for Spirituality, Dialogue \& Service

- Dolce Center for the Advancement of Veterans and Servicemembers (CAVS)

- Global Student Success, including the International Tutoring Center for help with English-language learning and academic success, Language \& Culture Workshops, and Reading Workshops

- Northeastern University Police Department

- Northeastern Writing Center for help with written work at any stage or type of assignment

- $\quad$ Peer and Alumni Mentoring

\section{$\underline{\text { Accommodations }}$}

Northeastern is fully committed to creating a community characterized by inclusion and diversity. As part of this commitment, it upholds the American with Disabilities Act as Amended of 2008 and the American with Disabilities Act and Section 504 of Rehabilitation Act, referred to collectively as the ADA. The ADA requires Northeastern to provide reasonable accommodations to students with disabilities unless doing so would create an undue hardship, compromise the health and safety of members of the university community, or fundamentally alter the nature of the university's employment mission. Students seeking information regarding ADA accommodations should review the University's ADA Information and Resources Procedure available here.

\section{$\underline{\text { Title IX }}$}

Northeastern is committed to providing equal opportunity to its students and employees, and to eliminating discrimination when it occurs. In furtherance of this commitment, the University strictly prohibits discrimination or harassment on the basis of race, color, religion, religious creed, genetic information, sex, gender identity, sexual orientation, age, national origin, ancestry, veteran, or disability status. The Northeastern University Title IX policy articulates how the University will respond to reported allegations of sexual harassment involving students, including sexual assault, and provides a consolidated statement of the rights and responsibilities under University policies and Title IX, as amended by the Violence Against Women Reauthorization Act of 2013.

Northeastern understands that some survivors of harassment, discrimination, sexual misconduct or other violations of this policy may not be ready or willing to report through a channel (such as to the Title IX Office or your instructor that could result in university action. For such individuals, the following confidential resources are available:

- ViSION Resource Center (VRC): (617) 373-4459

- University Health and Counseling Services (UHCS)

- Clergy in the Center for Spirituality, Dialogue and Service 


\section{POLS 4701 - Senior Capstone- Spring 2020 Mon/Thurs 11:45am - 1:25pm, Ryder 207}

Instructor: Colin M. Brown

Phone: (617) 373-8192

E-mail: colin.brown@northeastern.edu

Office: Renaissance Park 905

Formal Office Hours (sign up online): Monday 3:00 to 4:30 pm (or by appointment), RP 905

Informal Office Hours (drop-in): Monday 2:00 to 3:00, RP 905

\section{Overview}

Students graduating with a degree in political science will be expected to take an active role in the lives of their communities and in the intellectual conversation around politics and government. Much of what they will need to do will involve communicating and writing their ideas for the consumption of others. While most coursework has focused on the substance of politics and political science, this course will emphasize how to convey ideas, theories, opinions and data to a variety of audiences through extensive writing practice. The course will also teach students how to offer constructive feedback, and provide a wide variety of chances to give and receive criticism. It will also introduce students to a number of specific genres they may encounter in politics and/or as political scientists.

Students will focus all of their writing assignments on a single topic of interest. They are free to choose any topic that interests them or will prepare them for their future plans, but it must be consistent throughout the semester. In this way, students will be able to practice talking about the same topic in a variety of ways, and practice incorporating new material into existing ideas. Students should plan on completing a considerable amount of reading on their own and/or bringing in material from other courses, with the instructor available for advice and guidance.

\section{Course Learning Outcomes}

Students will be able to:

- Plan and write texts in a variety of styles appropriate to politics and to academic political science, including book reviews, literature reviews, editorial essays, public speeches, and research papers.

- Make revisions to their own writing based on peer review and critical feedback.

- Critique others' writing on political and academic topics in a way that allows others to improve writing and that shows interpersonal respect

- Assimilate new data and theories into existing arguments, and adapt existing arguments to new evidence. 


\section{Assignments}

- Participation - 30\%: Students are expected to attend all seminar and peer review sessions and at least some study halls, and to be heavily involved in the peer review process. You will also be expected to take part in discussions of the reading material for weeks where there are assigned readings and in-class discussions.

- Writing Assignments - 70\% Total: You will have a number of writing assignments due throughout the semester, and this will constitute the majority of your grade. The research paper will be worth $14 \%$ of your total grade, the academic book review will be worth $8 \%$, and the other assignments will each be worth $12 \%$ of your total grade. Each assignment's grade will be determined on the following factors:

- 20\% Timeliness

- $60 \%$ Satisfies the Goal of each Writing Style

- $20 \%$ Quality of Writing (applies only to revised drafts!)

Final course grades will be calculated from total percentages, without rounding $-\mathrm{A}: 94 \%$ or above $\%$, A-: $90 \%$ to $93.99 \%$, B+: $87 \%$ to $89.99 \%$, B: $83 \%$ to $86.99 \%$, B-: $80 \%$ to $82.99 \%$, C+: $77 \%$ to $79.99 \%$, C: $73 \%$ to $76.99 \%$, C-: $70 \%$ to $72.99 \%$, D+: $67 \%$ to $69.99 \%, F: 66.99 \%$ or below.

\section{Assignment Calendar (Is something due today?)}

For every day that a $1^{\text {st }}$ or $2^{\text {nd }}$ Draft is assigned, we will do peer review that day in class; plan to bring hard copies with you and to submit to Blackboard by the start of class on t (2:50pm) with the exception of the Research Paper, as noted below. All revised/final drafts are due on Blackboard by 11:59pm of the day indicated.

- January 23, by class: Academic Book Review $1^{\text {st }}$ Draft

- January 30, 11:59pm: Academic Book Review Revised

- February 6, by class: Popular Book Review $1^{\text {st }}$ Draft

- February 13 , by class: Op-Ed $1^{\text {st }}$ Draft

- February 20, 11:59pm: Op-Ed Revised \& Popular Book Review Revised

- March 9, by class: Literature Review $1^{\text {st }}$ Draft

- March 16, by class: Literature Review $2^{\text {nd }}$ Draft

- March 19, 11:59pm: Literature Review Revised

- March 26, by class: Guest Lecture or TED Talk $1^{\text {st }}$ Draft

- March 30 or April 2: Give Lecture or TED Talk (in class or recorded)

- April 7, 11:59pm: Research Paper $1^{\text {st }}$ Draft

- April 12, 11:59pm: Research Paper $2^{\text {nd }}$ Draft

- April 22, 11:59pm (during exams): Research Paper Final Draft

You will also have the opportunity to build on your own work from one assignment to the next. The style and intended audience will change for each piece so you cannot simply copy and paste entire paragraphs, but you can (and should) use prior work to scaffold and improve your later work, and as such you may use some ideas, phrases and/or sentences on multiple assignments. 


\section{Feedback}

Due to the volume of writing and the size of the class, the instructor will be unable to provide detailed feedback on every piece of writing. The instructor will, however a) join in in-class peer review, b) offer detailed feedback on the revised literature review, and c) offer detailed feedback on two other assignments of the student's choice

\section{Class Schedule}

\section{Seminars}

The following classes will focus on introducing new material, practicing writing or peer review skills, and/or discussing readings:

Jan. 6, 9, 12, \& 27; Feb. 3, 10, \& 24; Mar. 19; Apr. 6

\section{Peer Review Sessions}

The following classes will be centered on peer review of each other's writing, and will take place between the submission of first drafts and final drafts:

Jan. 23; Feb. 6* \& 13; Mar. 9, 16, \& 26; Apr. 9 \& 13

\section{Study Halls}

The following classes will be run like a faculty writing group-you are welcome to use the time to work on any aspect of your writing that you wish, and you can work independently or quietly in small groups. The instructor will be available for questions or to help consult on your writing. You must attend at least 2 of these, but you are encouraged to attend them all (and you will probably get more, better writing done if you do!):

Jan. 16; Feb. 20 \& 27; Mar. $12 \& 23$

\section{Reading Schedule}

This course is a chance for you to explore any topic that you have found interesting in your time as a political science student, and that you wish to examine in greater depth. You and your fellow students will be studying a wide range of themes and you may not overlap with what anyone else is doing---and that's fine! Your topic can evolve a bit as you read and discover things, but by January $16^{\text {th }}$, you should have worked with the instructor (via office hours or email) to determine a general topic that you will focus on for the semester.

Because of this opportunity to follow your own intellectual curiosity, the majority of reading you will do for this class will be on your own---you will be finding the materials you will draw on to write your literature review, book reviews, and research papers, and/or you will draw on things you have read before this class. While the assigned readings are relatively short, you should plan for considerable self-directed reading of books, academic articles, and reports. The instructor is always available to help you in your search, but this class is intended as an opportunity for intensive practice of the research skills you have acquired as an undergraduate. 


\section{Required Texts:}

- Gerald Graff and Cathy Birkenstein, They Say, I Say: The Moves That Matter in Academic Writing, W.W. Norton 2018 ( $4^{\text {th }}$ edition, but $3^{\text {rd }}$ edition is also fine---and likely cheaper)

Recommended Texts (short excerpts will be made available and copies are held for you on reserve at Snell Library, but many of you will find it worthwhile to purchase the full book so that you can read further and refer back to these)

- Steven Pinker, The Sense of Style: The Thinking Person's Guide to Writing in the $21^{\text {st }}$ Century, Penguin 2014

- Lisa Baglione, Writing a Research Paper in Political Science: A Practical Guide to Inquiry, Structure, and Methods, CQ Press 2015

Reading Assignments:

- January 9: Graff and Birkenstein, Introduction and Chapters 1-2

- January 13: Academic Book Review Examples (see Blackboard)

- January 27: Harvard Bureau of Study Counsel, "A Procrastinator's Guide to Writing" | Graff \& Birkenstein, Chapters 3-7

- January 30: Popular Book Review Examples (see Blackboard)

- February 3: Op-Ed Examples (see Blackboard)

- February 10: Selected Posts from Raul Pacheco-Vega's Blog (see Blackboard); Lisa Baglione Chapter 4

- February 24: Academic Literature Review Examples (see Blackboard)

- March 16: Graff \& Birkenstein, Chapters 8-10

- March 26: Carmine Gallo, Talk Like TED, Chapter 2 "Master the Art of Storytelling" \& Chapter 4 "Teach Me Something New"

- April 6: Lisa Baglione Chapter 7: "The Research Design" \& Chapter 8: "The Analysis and Assessment Section"

\section{Policies}

\section{Late Assignment Policy}

It is understood that students have a high workload and many different priorities during the semester. Therefore, any one revised version may be turned in late ${ }_{L}$ with no explanation needed. If you need to take this extension, simply e-mail the instructor before the due date indicating that your paper will be late. If the assignment is turned in less than 24 hours late, no grade penalty will be imposed. Otherwise, it can be turned in up to one week late at a $10 \%$ penalty (you may also get less feedback on your work). You may take either form of extension up to twice in the semester, and only on final drafts. 
Because of the importance of peer review, drafts cannot be turned in late barring sickness or emergencies, and you should communicate these to the instructor as soon as possible to ensure that you both receive and give adequate peer feedback.

\section{Academic Integrity}

The Department of Political Science takes very seriously the issue of academic honesty, and as set forth in Northeastern University's principles on Academic Honesty and Integrity Policy (the complete text can be found at Northeastern University's Office of Student Conduct and Conflict Resolution). Any student who appears to violate these principles will fail the course and will be put on academic probation. Individual faculty, with the support of the Department, can impose harsher penalties and as they deem necessary. Cheating is one example of academic dishonesty, and which is defined as using or attempting to use unauthorized materials, information, or study aids in any academic exercise. When completing any academic assignment, a student shall rely on his or her own mastery of the subject. Cheating includes plagiarism, which is defined as using as one's own the words, ideas, data, code, or other original academic material of another without providing proper citation or attribution. Plagiarism can apply to any assignment, either final or drafted copies, and it can occur either accidentally or deliberately. Claiming that one has "forgotten" to document ideas or material taken from another source does not exempt one from plagiarizing. Your instructor will clarify specific guidelines on fair use of material for this class.

Correct citation practices and academic honesty are an expectation of this course, but are also a skill students need to learn (and often need guidance on). If you are uncertain what to do in a situation, do not hesitate to ask the instructor beforehand to avoid creating a larger issue later.

\section{Resources}

\section{Campus Resources \& Services}

Students may face many barriers to learning in the course of their education, such as anxiety, depression, substance abuse, strained familial or romantic relationships, and others. Northeastern University provides you with a number of resources that may help you in whatever challenges you face, and help you find the space to succeed in your studies. University Health and Counseling Services (617-373-2772) has a wide variety of resources open to you, as do the centers and offices below:

- Center for Spirituality, Dialogue \& Service

- Dolce Center for the Advancement of Veterans and Servicemembers (CAVS)

- Global Student Success, including the International Tutoring Center for help with English-language learning and academic success, Language \& Culture Workshops, and Reading Workshops

- $\quad$ Northeastern University Police Department

- Northeastern Writing Center for help with written work at any stage or type of assignment

- $\quad$ Peer and Alumni Mentoring 


\section{Accommodations}

Northeastern is fully committed to creating a community characterized by inclusion and diversity. As part of this commitment, it upholds the American with Disabilities Act as Amended of 2008 and the American with Disabilities Act and Section 504 of Rehabilitation Act, referred to collectively as the ADA. The ADA requires Northeastern to provide reasonable accommodations to students with disabilities unless doing so would create an undue hardship, compromise the health and safety of members of the university community, or fundamentally alter the nature of the university's employment mission. Students seeking information regarding ADA accommodations should review the University's ADA Information and Resources Procedure available here.

\section{Title IX}

Northeastern is committed to providing equal opportunity to its students and employees, and to eliminating discrimination when it occurs. In furtherance of this commitment, the University strictly prohibits discrimination or harassment on the basis of race, color, religion, religious creed, genetic information, sex, gender identity, sexual orientation, age, national origin, ancestry, veteran, or disability status. The Northeastern University Title IX policy articulates how the University will respond to reported allegations of sexual harassment involving students, including sexual assault, and provides a consolidated statement of the rights and responsibilities under University policies and Title IX, as amended by the Violence Against Women Reauthorization Act of 2013.

Northeastern understands that some survivors of harassment, discrimination, sexual misconduct or other violations of this policy may not be ready or willing to report through a channel (such as to the Title IX Office or your instructor that could result in university action. For such individuals, the following confidential resources are available:

- ViSION Resource Center (VRC): (617) 373-4459

- University Health and Counseling Services (UHCS)

- Clergy in the Center for Spirituality, Dialogue and Service 